Abstracta Iranica Abstracta Iranica

Revue bibliographique pour le domaine irano-aryen

Volume 22 | 2001

Comptes rendus des publications de 1999

\title{
Pamir - strana ariev. Douchanbeh, Institut gumanitarnyx nauk, 1997, 196 p. [Pamir, Land of the Aryans]
}

\section{Saodat Olimova}

\section{(2) OpenEdition}

Journals

Édition électronique

URL : http://journals.openedition.org/abstractairanica/36794

DOI : 10.4000/abstractairanica.36794

ISSN : 1961-960X

Éditeur :

CNRS (UMR 7528 Mondes iraniens et indiens), Éditions de l'IFRI

\section{Édition imprimée}

Date de publication : 15 mai 2001

ISSN : 0240-8910

Référence électronique

Saodat Olimova, "Pamir - strana ariev. Douchanbeh, Institut gumanitarnyx nauk, 1997, 196 p. [Pamir, Land of the Aryans] », Abstracta Iranica [En ligne], Volume 22 | 2001, document 352, mis en ligne le 17 février 2010, consulté le 13 octobre 2020. URL : http://journals.openedition.org/abstractairanica/ 36794 ; DOI : https://doi.org/10.4000/abstractairanica.36794

Ce document a été généré automatiquement le 13 octobre 2020.

Tous droits réservés 


\section{Pamir - strana ariev. Douchanbeh, Institut gumanitarnyx nauk, 1997, 196 p. [Pamir, Land of the Aryans]}

\section{Saodat Olimova}

1 The work consists in three articles. The first two articles: "Pamir - Land of the Aryans », and « Arya Religion - Harmony of Two Worlds » are in Russian and translated to English. The third article « The House of the Truth Followers » is written in Tajik in Cyrillic and Arabic alphabets. All the articles are dedicated to the pre-islamic culture and Ismailism.

INDEX

Thèmes : 7. Islam

\section{AUTEURS}

SAODAT OLIMOVA

Dushanbe (Tadjikistan) 